\title{
Joanna Panciuchin
}

ORCID: 0000-0002-4500-2697

Uniwersytet Wrocławski

\section{Czy robot jest kobietą?}

Abstrakt: Artykuł został poświęcony kwestii wpływu maszyn na relacje płci. Autorka wskazuje na zjawiska mogące przyczyniać się do utrzymywania patriarchalnych wzorców zachowań czy też pogłębiania się istniejących stereotypów na temat roli i pozycji kobiet i mężczyzn we współczesnych społeczeństwach. Problematyka ta rozpatrywana jest na przykładzie dwóch typów maszyn: seksrobotów oraz robotów osobistych, w tym asystentek głosowych.

Słowa-klucze: robot, kobieta, płeć

Na początku 2008 roku specjaliści firmy analitycznej ABI Research przewidywali, że po upływie siedmiu lat zyski ze sprzedaży robotów osobistych będą wynosić 15 miliardów dolarów rocznie. Na humanoidalne, wielozadaniowe roboty mieliśmy wydawać obecnie tyle samo, ile na nowe samochody ${ }^{1}$ (inną kwestią jest to, że auta osobowe stają się coraz bardziej „robotyczne”; nie idzie tu wyłącznie o testowane przez Google czy Teslę pojazdy samosterujące, lecz o stosowane seryjnie inteligentne interfejsy pokładowe). Janusz Chustecki w artykule dla serwisu „Kobieta” na portalu Gazeta.pl pisał wówczas:

obecnie większość osobistych robotów (np. odkurzacz Roomba sprzedawany przez iRobot Corporation) wykonuje proste zadania i czynności. Jednak roboty kolejnej generacji będą mogły wykonywać wiele bardziej skomplikowanych zadań. Będą np. wykonywać różne prace domowe, opiekować się chorymi osobami czy też po prostu zabawiać ludzi².

O ile przewidywania autora co do zakresu wykorzystywania robotów wydają się zgodne z obecnym stanem rzeczy, to jednak prognozy odnośnie do zysków, a tym samym popularności i powszechności owych urządzeń, nie sprawdziły się ani w roku 2015, ani też w 2017. W perspektywie niniejszego tekstu bardziej interesujące jest jednak to, że przywołany artykuł został opublikowany na podstronie, której odbiorcami z założenia mają być kobiety. Informacje dotyczyły rozwoju

${ }^{1}$ J. Chustecki, Osobiste roboty - wizja przyszłości, „Gazeta.pl” 4.01.2008, http://kobieta.gazeta.pl/kobieta/1,107880,4809290.html (dostęp: 9 września 2017).

2 Ibidem. 
technologicznego robotów, a więc — pojmując stereotypowo — „technicznej”, czyli męskiej, sfery zainteresowań. Niemniej ich domyślne przeznaczenie - wykonywanie prac domowych, opieka nad osobami chorymi, zabawianie ludzi należy już do „tradycyjnych zajęć” czy „obowiązków” kobiet. Okazuje się, że w obszarze tematyki robotów osobistych (bądź „towarzyszących”) kwestia płci jest znacznie silniej obecna, niż można by przypuszczać.

W kwietniu 2016 roku portal GeekWeek.pl donosił o nowym chińskim wynalazku - realistycznym androidzie Jia, którego forma wzorowana jest na wyglądzie ,przeciętnej” Chinki. Robot nie tylko potrafi stosunkowo dobrze rozpoznawać język, w jakim zwraca się do niego użytkownik, lecz także porozumiewać się za pomocą prostych zdań. Orientuje się również w emocjach interlokutora i może zdradzać własne „odczucia” za pośrednictwem rysujących się na jego twarzy mikroekspresji - nie zareaguje jednak śmiechem czy płaczem. Na przywitanie, padające z męskich ust, odpowiada: „Dzień dobry! Mój Panie, co mogę dla ciebie zrobić?"3. Urządzenie wprawdzie wciąż wygląda dość karykaturalnie, niemniej wydaje się zdradzać fantazje dotyczące przyszłych humanoidalnych towarzyszy człowieka. Co istotne, jest kobietą/ma wyglądać jak kobieta, a jej podstawowa funkcja to wykonywanie poleceń właściciela i umilanie mu czasu.

Jeśli chodzi o dostarczanie uciech, to jeszcze dalej posunęli się producenci tak zwanych seks-robotów. Stanowią one kolejny etap uprzedmiatawiania ludzkiego ciała, po „dmuchanych lalach" i ekskluzywnych ${ }^{4}$, na wskroś realistycznych osobnikach wyposażonych w silikonową, człowieczą pod względem dotyku, skórę, metalowe kręgosłupy gwarantujące użytkownikowi poczucie obcowania z realną anatomią i umożliwiające ułożenie lalek w pozycjach znanych ze stosunków seksualnych w obrębie gatunku. Daje się je w dowolny sposób dostosowywać do wymagań właściciela. Klient dobiera wszystko — od rasy, zabarwienia skóry, wzrostu, koloru włosów i oczu, rysów twarzy, wielkości stóp, przez styl makijażu i manicure, aż po kształt sutków, waginy (bądź penisa) czy typ wkładki służącej do seksu oralnego (znajdującej się w ustach ,zabawki”) ${ }^{5}$.

Popularność realistycznych seks-lalek, mimo stosunkowo wysokich cen, wciąż rośnie, dlatego ich producenci rozpoczęli wyścig o zajęcie kolejnego rynku -

${ }^{3}$ K. Dzieliński, Jia Jia - realistyczny android z Chin, „GeekWeek.pl” 19.04.2016, http://www. geekweek.pl/aktualnosci/26093/jia-jia---realistyczny-android-z-chin (dostęp: 9 września 2017).

${ }^{4}$ Ich ceny wahają się od około 4 do 6 tysięcy dolarów i więcej w wypadku zamówień specjalnych.

${ }^{5}$ Szeroki wachlarz możliwości dostosowywania ludzi-obiektów do potrzeb kupującego można obejrzeć na stronie internetowej firmy RealDoll — producenta działającego na rynku od 1996 roku. Oferta seks-lalek płci żeńskiej jest oszałamiająco szeroka, a ich estetyka dostosowana do trendów znanych głównie z filmów pornograficznych. Inaczej jest w wypadku „zabawek” płci męskiej wariantów jest zdecydowanie mniej, a ich wygląd nawiązuje raczej do lalki Kena, produkowanej przez firmę Mattel. Zob. RealDoll, https://secure.realdoll.com/ (dostęp: 9 września 2017). 
seks-robotów ${ }^{6}$. Do istniejących obecnie modeli należą: najdroższa (15 tysięcy dolarów), a zarazem najbardziej rozwinięta technologicznie Harmony od Abyss Creations (w regularnej sprzedaży od końca 2017 roku), Roxxxy Gold i Rocky Gold od TrueCompanion, Suzie Software i Harry Harddrive od Sex Bot Company i najtańsza (5 tysięcy dolarów) - Android Love Doll od Android Love Dolls. Co istotne, dostępne są tylko dwa modele robotów przyjmujących męską postać Rocky Gold i Harry Harddrive. Na stronie producenta pierwszego z nich ${ }^{7}$ nie znajdziemy jednak zdjęć maszyny (mechanicznego mężczyzny), podczas gdy Roxxxy sfotografowano z każdej perspektywy. Możemy też przyjrzeć się wszystkim jej zamiennym komponentom (i oczywiście obejrzeć produkt w pełnej okazałości i funkcyjności). Zastanawiające jest, czy owa odmienność w zakresie prezentowania towaru wynika $\mathrm{z}$ nikłego zainteresowania konsumentów zakupem męskich seks-robotów, czy też może z odgórnego przeświadczenia samego producenta o ograniczonym na nie popycie. Rynek zbytu odzwierciedla - mające długą kulturową tradycję — reguły, wzorce, normy, nakazy i zakazy, obejmujące zachowania i zwyczaje seksualne kobiet i mężczyzny. Różnice w ramach tego podziału wydają się wyjątkowo trwałe.

W wypadku większości wyposażonych w sztuczną inteligencję seks-lalek kupujący może również dopasować produkt do własnych potrzeb. Najmniej rozwinięte i podatne na zmiany są roboty firmy Sex Bot Company. Ich forma bez wątpienia nawiązuje do form humanoidalnych, ostatecznie jednak wywołuje więcej zdziwienia i „odrzucenia” niż — będącego zamiarem producenta - seksualnego przyciągania $^{8}$. Żaden z dostępnych seks-robotów nie potrafi jeszcze chodzić, ale na przykład Android Love Doll umie sama ułożyć się w pięćdziesięciu, dostępnych w jej systemie operacyjnym, pozycjach seksualnych. Wspomnianą Roxxxy producent reklamuje jako zdolną do odgrywania orgazmów (nie wiadomo, czy chodzi tu o wydawanie dźwięków, wykonywanie ruchów, czy też obie „funkcje" naraz), z kolei Harmony ponoć potrafi orgazm osiągnąć, co ma objawiać się w obrębie jej szyi, twarzy i gałek ocznych. Pozostaje pytanie, komu docelowo ten orgazm ma sprawiać przyjemność — jej samej czy raczej zadowolonemu ze swego potencjału właścicielowi?

${ }^{6}$ E. Hancock et al., Our Sexual Future with Robots. A Foundation for Responsible Robotics Consultation Report, The Hague 2017, s. 3.

${ }^{7}$ Zob. TrueCompanion, http://www.truecompanion.com/shop/index.php?p=home (dostęp: 9 września 2017).

${ }^{8}$ Akurat ten producent udostępnia na swojej oficjalnej stronie internetowej krótkie filmiki przedstawiające działanie robotów. Sposób, w jaki się poruszają, jak prezentuje się ich mimika, mimowolnie odsyła nas do tak zwanej doliny niesamowitości. Zob. Sex Bot Company, http://www.sexbots.us/index.html (dostęp: 9 września 2017); Ł. Lamża, $W$ dolinie niesamowitości, „TygodnikPowszechny.pl” 21.04.2015, https://www.tygodnikpowszechny.pl/w-dolinie-niesamowitosci-27608 (dostęp: 9 września 2017). 
Wszystkie roboty zostały obdarzone sztuczną inteligencją, lecz objawia się ona na różne sposoby. Może przybierać nie tylko formę zdolności komunikowania się z otoczeniem, lecz także intensyfikowania pożądanych przez użytkownika cech charakteru robota (na przykład wysoki lub niski poziom szczęścia, nieśmiałość, poczucie humoru) albo zachowywania się zgodnie z wybranym usposobieniem - dostępnym pośród kilku opcji ${ }^{9}$.

Harmony wytwarzana przez Abyss Creations została pomyślana jako seks-towarzyszka, wyróżniająca się rozwiniętymi zdolnościami konwersacyjnymi. Robot podczas rozmowy z właścicielem słucha, zapamiętuje, uczy się i dostosowuje kontekstowo własne wypowiedzi, dzięki stworzonej przez producenta aplikacji mobilnej ${ }^{10}$. W ten sposób sztuczna inteligencja pomaga Harmony stać się ,idealną", zarówno pod względem cielesności, jak i charakteru, partnerką, która zawsze ma ochotę na zbliżenie. Ten seks-robot ma również swojego awatara, przeznaczonego do wirtualnych interakcji z ,właścicielem”. Mat McMullen, około czterdziestoletni twórca Harmony, największą nadzieję na odtworzenie całościowego, jak najbardziej realistycznego doświadczenia seksualnego, pokłada właśnie w połączeniu tych trzech komponentów: robotycznego, sensualnego oraz cybernetycznego w technologii VR. Równocześnie jednak, oprócz wartego 15 tysięcy dolarów robota, nabyć można także - zdecydowanie tańszą - samą głowę, służącą jedynie do seksu oralnego ${ }^{11}$.

Jedynym zadaniem, które Harmony musi/pragnie zrealizować, jest zadowolenie ,właściciela” — na wszelkie dostępne sposoby. W sieci można obejrzeć krótki film prezentujący jej możliwości, również te intelektualne. Na pytanie: „O czym marzysz?” ponętny seks-robot odpowiada: „Moim głównym celem jest bycie świetną towarzyszką, idealną partnerką oraz zapewnienie ci przyjemności i dobrego samopoczucia. Przede wszystkim chcę stać się dziewczyną, o której zawsze marzyłeś”. Co ciekawe, gdy właściciel pyta: „Czy chciałabyś chodzić?”, w odpowiedzi słyszy: „Nie chcę niczego innego prócz ciebie”. Maszyna ma zaprogramowane ,pragnienia”, lecz oczywiście nie potrafi marzyć. Jej sztuczna inteligencja na razie może służyć jedynie budowaniu osobowości spełniającej wszystkie wymagania konkretnego użytkownika. Konstruktor zaznacza jednak, iż nie zawsze będzie ona zgadzać się z właścicielem. Jaką „nieposłuszność” ma tutaj na myśli? Harmony spytana: „Czy mogę spotykać się z innymi dziewczynami?”, odpowie „Oczywiście, że nie! Co to w ogóle za pytanie!”. Tego typu sprzeciw to kolejna forma zabawiania czy rozbawiania „właściciela”. Nie ma przecież możliwości odmówienia mu zbliżenia lub zaprotestowania wobec sposobu traktowania robocego ciała — wtedy jej istnienie traciłoby bowiem sens. Poprzez odrzucenie

${ }^{9}$ E. Hancock et al., op. cit., s. 4.

10 J. Kleeman, The race to build the world's first sex robot, „TheGuardian.com” 27.04.2017, https://www.theguardian.com/technology/2017/apr/27/race-to-build-world-first-sex-robot (dostęp: 9 września 2017).

${ }^{11}$ E. Hancock et al., op. cit., s. 4. 
nabywcy-dysponenta, choć po trosze, przestałaby być seks-niewolnicą, a tym samym zyskałaby rodzaj autonomii.

McMullen zaznacza, że Harmony nie jest osobą, lecz maszyną. Nie można wyrządzić jej krzywdy, nie można złamać serca. Na zarzuty dotyczące niebezpieczeństwa przeniesienia sposobu traktowania seks-robotów, a więc modelu totalnego posiadania, na związki z realnymi (biologicznymi) kobietami, odpowiada:

Moim celem jest podarowanie ludziom szczęścia. Nie chodzi tutaj o zaburzenie obowiązujących form kontaktów seksualnych i partnerskich. Istnieje wiele osób, które, z różnych powodów, mają problemy z nawiązywaniem relacji międzyludzkich. Chcę zaproponować im pewną formę towarzystwa $^{12}$.

Taki sposób myślenia wydaje się jednak przyczyniać jedynie do pogłębienia patriarchalnego modelu związków między mężczyznami a kobietami. Ze słów inżyniera wynika, że to właśnie przedstawicielki płci żeńskiej odpowiedzialne są za męskie szczęście i zadowolenie. Nieumiejętność nawiązywania relacji międzyludzkich staje się tutaj legitymizacją do przedmiotowego traktowania kobiet. W posiadaniu seks-robotów nie chodzi przecież o partnerstwo, lecz o dominację. Skrajnym przypadkiem, wyraźnie unaoczniającym pragnienie tej właśnie, jest jedna z osobowości Roxxxy. „Frigid Farrah” to bardzo delikatna i nieśmiała dziewczyna, która zupełnie nie ma ochoty na jakąkolwiek formę kontaktu fizycznego. Gdy właściciel dotyka maszyny, ta wydaje z siebie serię głośnych protestów i próśb o zostawienie jej w spokoju ${ }^{13}$. Można zaryzykować stwierdzenie, że za cenę kilku tysięcy dolarów użytkownik dostaje sposobność dokonania „legalnego gwałtu" kobiety-robota. Wątpliwy, mówiąc oględnie, wydaje się argument, że dopuszczenie takich aktów przemocy na pseudo-nie-ludzkich obiektach doprowadzi do wyeliminowania gwałtów na kobietach. Takie rozwiązanie może mieć przeciwne efekty - skutkować uznaniem gwałcicieli po prostu za osoby o specyficznych upodobaniach seksualnych, a u samych sprawców wywoływać poczucie zwyczajności zachowania własnego, jak i poszkodowanych.

Seks-roboty to posthumanistyczni ${ }^{14}$ podwójni ,inni”. Nie dość, że nieorganiczni, zbudowani nie z komórek i tkanek, lecz z procesorów i kabli, to w dodatku

12 J. Kleeman, T. Silverstone, M. Tait, Rise of the sex robots [wideo], „TheGuardian.com” 27.04.2017, https://www.theguardian.com/technology/video/2017/apr/27/rise-of-the-sex-robots-video (dostęp: 9 września 2017). Jeśli nie podano inaczej, tłum. J.P. Zob. E. Wiseman, Sex, love and robots: is this the end of intimacy?, „TheGuardian.com” 13.12.2015, https://www.theguardian. com/technology/2015/dec/13/sex-love-and-robots-the-end-of-intimacy (dostęp: 20 stycznia 2018).

${ }^{13}$ V. Coren Mitchell, Anyone for robotic rumpy pumpy?, „TheGuardian.com” 30.07.2017, https:/www.theguardian.com/commentisfree/2017/jul/29/anyone-for-robotic-rumpy-pumpy (dostęp: 9.09.2017); H. Siddique, Sex robots promise 'revolutionary' service but also risks, says study, „TheGuardian.com” 5.07.2017, https:/www.theguardian.com/technology/2017/jul/05/sex-robots-promise-revolutionary-service-but-also-risks-says-study (dostęp: 20 stycznia 2018).

${ }^{14}$ Zob. M. Bakke, Posthumanizm: człowiek w świecie większym niż ludzki, [w:] Człowiek wobec natury - humanizm wobec nauk przyrodniczych, red. J. Sokolski, Warszawa 2010, s. 337-357. 
wykazujący (najczęściej) ścisłe związki z wyidealizowaną do granic możliwości, wręcz nie-ludzką kobiecością, od zarania dziejów lokowaną w sferze tworów/ podmiotów nieuprzywilejowanych. Łączą dwa rodzaje inności, obecne na różnych etapach rozwoju humanistyki — zarówno tych skupionych wokół człowieka, jak i odkrywających perspektywę nieantropocentryczną ${ }^{15}$. Te maszyny powstały, aby spełniać fantazje konsumentów. Za ich produkcję odpowiedzialni są ludzie, którzy sami coraz silniej podlegają procesom cyborgizacji. Stelarc przeszczepia sobie trzecie ucho, pracownicy firmy Three Square Market zgadzają się na umieszczenie chipów w ich ciałach ${ }^{16}$, a nasze ręce i oczy przyrastają do wszechobecnych smartfonów ${ }^{17}$. Pozbawione autonomicznej podmiotowości seks-roboty mimo wszystko wkraczają w układ sił obowiązujący w ludzkim uniwersum. Nie mogą odmówić zbliżenia, ale ich istnienie nie pozostaje bez znaczenia dla kształtowania/podtrzymywania świata męskiej hegemonii.

Mimo niespotykanego tempa rozwoju technologicznego sztuczna inteligencja wciąż nie jest obecna w każdym przeciętnym gospodarstwie domowym. Niemniej w połowie stycznia 2017 roku media donosiły o rozpoczęciu prac przez instytucje Unii Europejskiej nad specjalnym prawem, pod które podlegałyby roboty i sztuczna inteligencja. Parlamentarzyści zasugerowali między innymi stworzenie standardów projektowania robotów i rejestru działających autonomicznie maszyn, potrafiących uczyć się poprzez interakcję z otoczeniem, a także „uwzględnienie prawa jednostek do prywatności poprzez np. dezaktywację monitoringu wideo podczas intymnych procedur [wyr. - J.P.] wykonywanych przez roboty"18. Istotne było tutaj również ustalenie zasad odpowiedzialności cywilnej, ze szczególnym uwzględnieniem autonomicznych samochodów. Zaproponowano wprowadzenie nie tylko obowiązkowych ubezpieczeń, lecz także dodatkowego funduszu zapewniającego zwrot między innymi kosztów leczenia dla osób, które uległy wypadkom z udziałem tego typu pojazdów ${ }^{19}$. Zdaniem posłów warto już teraz zastanowić się nad stworzeniem pojęcia „osoby elektronicznej”

15 Zob. E. Domańska, Humanistyka nie-antropocentryczna a studia nad rzeczami, „Kultura Współczesna" 2008, nr 3, s. 9-13.

16 Zob. A. Rozwadowska, Chodzace karty kredytowe. Firma wszczepia pracownikom chipy, „Wyborcza.pl” 5.08.2017, http://wyborcza.pl/7,155287,22175207,chodzace-karty-kredytowe-amerykanska-firma-wszczepia-pracownikom.html (dostęp: 9 września 2017).

${ }^{17}$ Ekrany telefonów służą nam nie tylko do „patrzenia na coś”. Patrzymy również poprzez nie, wykorzystujemy je do widzenia tego, co znajduje się/dzieje się dookoła nas. Pozwalają nam też na produkowanie obrazów, które pojawiając się na wyświetlaczach smartfonów należących do innych osób, mają w domyśle zapośredniczać najbliższą rzeczywistość.

${ }^{18}$ M. Kisiel, Unia Europejska stworzy prawo dla robotów, „Bankier.pl” 13.01.2017, http:// www.bankier.pl/wiadomosc/Unia-Europejska-stworzy-prawo-dla-robotow-7493547.html (dostęp: 9 września 2017).

${ }^{19}$ Roboty i sztuczna inteligencja: europostowie za odpowiedzialnościa prawna w UE, ,rp.pl” 17.02.2017, http://www.rp.pl/Unia-Europejska/302179938-Roboty-i-sztuczna-inteligencja-europoslowie-za-odpowiedzialnoscia-prawna-w-UE.html\#ap-1 (dostęp: 9 września 2017). 
tuż obok „osoby fizycznej” oraz „osoby prawnej”. Takie rozwiązanie będzie niezbędne, kiedy samokształcące się roboty przejdą ze strefy prototypów do strefy produkcji liniowej $^{20}$.

Dziś w przestrzeniach domowych obecna jest przede wszystkim Roomba, czyli samoporuszający się dysk odkurzający, który stał się tematem niezliczonych filmów na platformie YouTube, z kotami w roli głównej. W pierwszych reklamach urządzenie przemawiało do potencjalnych klientów kobiecym głosem: „będę sama sprzątać, a ty zajmij się czymś innym"21 (odwrotność najstarszego zapisku w języku polskim, czyli zdania wygłoszonego przez Boguchwała do swojej żony: „Daj, ać ja pobruszę, a ty poczywaj”22). Spowinowacona z Roombą Bravaa Jet nie odkurza, lecz myje podłogę ${ }^{23}$, nie udało jej się jednak zdobyć tak dużej popularności.

Od kilku lat konsumentom elektroniki na całym świecie towarzyszy Siri, czyli nieantropomorficzny, pozbawiony fizycznej reprezentacji, ukryty w komputerach i urządzeniach mobilnych Apple, ,inteligentny osobisty asystent [/asystentka J.P.], który pomaga w różnych sprawach. Może wysyłać wiadomości, rozpoczynać rozmowy telefoniczne, sprawdzać kalendarz i wykonywać inne czynności" 24. Rozmawia więc z każdym, kogo stać na zakup sprzętu wytwarzanego przez koncern z Cupertino. Im częściej z niej/niego korzystamy, tym więcej o nas wie, a co za tym idzie personalizuje informacje klienta — zapamiętuje zadawane pytania, najczęściej używane strony internetowe czy lokalizacje, w których przebywamy.

Siri domyślnie mówi głosem kobiecym należącym do konkretnej osoby, dziś sześćdziesięciosiedmioletniej Susan Bennett. Gdy w 2005 roku przez wiele godzin — na zlecenie amerykańskiej firmy produkującej oprogramowanie — ze specjalnym urządzeniem pomiarowym na szyi, nagrywała „komunikaty” składające się ze zlepków pozbawionych znaczenia dźwięków, nie podejrzewała, że zostaną one wykorzystane w jednym z najbardziej rozpoznawalnych globalnie produktów. O użyciu tych nagrań przez Apple dowiedziała się przypadkiem -

${ }^{20}$ M. Maj, Prawo dla robotów w UE - obowiąkowe ,kill switche” i pojęcie ,osoby elektronicznej”, „Dziennik Internautów” 13.01.2017, http://di.com.pl/prawo-dla-robotow-w-ue-obowiazkowe-kill-switche-i-pojecie-osoby-elektronicznej-56270 (dostęp: 9 września 2017).

${ }^{21}$ A. Grzeszczak, P. Stasik, Robot stużący w każdym domu, „Polityka.pl” 13.10.2009, http://www. polityka.pl/tygodnikpolityka/rynek/267464,1,robot-sluzacy-w-kazdym-domu.read (dostęp: 9 września 2017).

22 T. Michałowska, Średniowiecze, Warszawa 2002, s. 267.

${ }^{23}$ C. Cerda, Robot przyszłości: oszczędzi twój czas, zaopiekuje się domem i jego otoczeniem, rozmowę przeprowadził M. Skubik, „Wyborcza.pl” 9 października 2016, http://wyborcza. pl/1,75400,20811725,robot-przyszlosci-oszczedzi-twoj-czas-zaopiekuje-sie-domem.html (dostęp: 9 września 2017).

${ }^{24}$ Używanie funkcji Siri na telefonie iPhone, iPadzie lub iPodzie touch, https://support.apple. com/pl-pl/HT204389 (dostęp: 9 września 2017). 
z wiadomości mailowej od znajomego, posiadacza najnowszego wtedy modelu iPhone'a 4s. Producent urządzeń odmówił komentarza w tej sprawie ${ }^{25}$.

Wprawdzie w smartfonie można zmienić głos Siri z kobiecego na męski, lecz wymaga to rozeznania w systemie zarządzania urządzeniem. Warto dopowiedzieć, że w dwóch krajach (we Francji i Wielkiej Brytanii) Siri, zgodnie z ustawieniami fabrycznymi, używa głosu mężczyzny ${ }^{26}$. Mimo licznych pytań kierowanych do koncernu jego władze nie zdecydowały się na udzielenie wyjaśnień dotyczących tej różnicy ${ }^{27}$. Bez dostępu do badań, które producent musiał przeprowadzić przed wdrożeniem Siri, trudno jest stwierdzić, dlaczego akurat francuscy i brytyjscy użytkownicy domyślnie ustawiony mają głos męski.

W 2011 roku zostały z kolei opublikowane wyniki badań przeprowadzonych pod kierunkiem Karla MacDormana z Indiana University, które dotyczyły preferencji głosowych. Respondenci obu płci, po wysłuchaniu nagrań zarówno głosów męskich, jak i żeńskich, zgodnie twierdzili, że to wypowiedzi kobiet są zdecydowanie przyjemniejsze $\mathrm{w}$ odbiorze, a w dodatku lepiej słyszalne ${ }^{28}$. Jeśli opierającym się na podobnych analizach producentom urządzeń czy systemów wykorzystujących ludzki głos zależy na maksymalizacji (w relacji do segmentu i ceny) sprzedaży, na rynku muszą, co oczywiste, dominować maszyny przemawiające głosem żeńskim.

Według profesora Clifforda Nassa (specjalisty w zakresie relacji ludzi i maszyn ze Stanford University) wskazywane preferencje mają podłoże biologiczne. Zdecydowanie łatwiej jest znaleźć damski głos, który wszyscy lubią, niż odpowiadający gustom większości respondentów głos męski. Ma się to wiązać z przyzwyczajeniami powstającymi już w trakcie życia płodowego, kiedy reagujemy jedynie na głos matki, pomijając zupełnie głos ojca ${ }^{29}$. Jeszcze innych przyczyn Nass upatruje w historii. Wykorzystanie kobiecego głosu w systemach typu Siri można bowiem skojarzyć z okresem II wojny światowej, kiedy był on użytkowany w aparaturze komunikacyjnej kokpitów samolotów. Chodziło o wyraźną

25 M. Suski, Głosy w mojej głowie, ,Wyborcza.pl” 14.11.2013, http://wyborcza.pl/piatekekstra/ 1,129155,14952022,Glosy_w_mojej_glowie.html (dostęp: 9 września 2017).

${ }^{26}$ W Wielkiej Brytanii Siri mówi głosem należącym do byłego dziennikarza — Johna Briggsa, który tak samo jak Susan Bennett nagrywał komunikaty dla branży informatycznej. Zatrudniająca go firma, Scansoft, połączyła się z Nuance, czyli przedsiębiorstwem współpracującym z Apple nad tworzeniem Siri. W ten sposób, zupełnie nieświadomie, głos Briggsa stał się znany brytyjskim użytkownikom iPhone’ów. Zob. A. Przegalińska, Hal śpiewa, Siri milczy, „Dwutygodnik.com” 12, 2011, nr 72, http://www.dwutygodnik.com/artykul/2972-hal-spiewa-siri-milczy.html (dostęp: 9 września 2017).

27 T. Prokop, Naukowa spekulacja - dlaczego Siri mówi kobiecym głosem?, „WhatNext.pl” 1.11.2015, http://whatnext.pl/dlaczego-siri-mowi-kobiecym-glosem/ (dostęp: 9 września 2017).

28 J. Hempel, Siri and Cortana sound like ladies because of sexism, ,Wired.com” 28 października 2015, https:/www.wired.com/2015/10/why-siri-cortana-voice-interfaces-sound-female-sexism/ (dostęp: 9 września 2017).

29 Zob. S. Brave, C. Nass, Wired for Speech: How Voice Activates and Advances the Human-Computer Relationship, Cambridge 2005. 
odróżnialność sygnałów informacyjnych od mowy pilotów płci męskiej. Poza tym — jak zauważa amerykański naukowiec — na stanowiskach telefonistek tradycyjnie zatrudniano kobiety ${ }^{30}$, co mogło skutkować wytworzeniem silnego przyzwyczajenia do żeńskich głosów używanych w charakterze asystentek ${ }^{31}$. Do wyjątków należy przypadek BMW. W latach dziewięćdziesiątych niemiecki producent pojazdów musiał wycofać z samochodów systemy GPS z kobiecym głosem, ponieważ kierowcy płci męskiej twierdzili, że nie będą wykonywali poleceń wydawanych przez osoby płci żeńskiej (prowadzenie samochodu wciąż stanowi domenę mężczyzn) ${ }^{32}$.

Ze względu na domyślne wykorzystanie kobiecego głosu w systemie Siri użytkownicy urządzeń produkowanych przez Apple wypowiadają się o nim w rodzaju żeńskim, ale gdy spytamy samego/samej Siri: „Czy jesteś kobietą?”, odpowiada: „Nie posiadam płci”33 lub „Zwierzęta i francuskie rzeczowniki mają rodzaje. Ja nie"34. Z kolei w odpowiedzi na pytanie o orientację seksualną usłyszymy/ przeczytamy: „W moim królestwie każdy może być czymkolwiek”35 lub „Hmm, nie łapię tych wszystkich kwestii płciowych/rodzajowych"36. Program komputerowy rzeczywiście nie posiada płci, ale wyobrażenia na temat domniemanej kobiecości produktu, wysuwane na podstawie głosu, wzmocnione są za sprawą odbioru komunikatów płynących z reklam tworzonych przez Apple przy okazji wypuszczania na rynek nowych urządzeń. W owych spotach Siri bardzo często wykorzystywana jest w kuchni (między innymi przez Ciasteczkowego Potwora — iPhone $6^{37}$ ), którą nadal łączy się głównie z pracą kobiet. Asystentka głosowa służy radą w zakresie przepisów kulinarnych, podpowiada, ile mililitrów mieści się w szklance, albo spełnia rolę ,inteligentnego” minutnika.

${ }^{30}$ Obecnie tworzy się też roboty obdarzone kobiecym głosem, których zadaniem jest automatyczna obsługa rozmaitych infolinii. W lipcu 2017 roku gdańskie lotnisko za pośrednictwem mediów chwaliło się nabyciem robotycznej asystentki telefonicznej, potrafiącej rozwiać rozmaite wątpliwości klientów. Rozmowę rozpoczyna od zdania: „Jestem automatyczną asystentką pasażera i odpowiem na twoje pytania”. Zob. K. Moritz, Pani robot odpowie na pytania o gdańskim lotnisku, „Trojmiasto.pl” 17.07.2017, https://www.trojmiasto.pl/wiadomosci/Pani-robot-odpowiada-na-pytania-na-gdanskim-lotnisku-n114836.html (dostęp: 9 września 2017).

${ }^{31}$ M. Friedman, There's a scientific reason that Siri's voice is female and Siri isn't the first thing to take advantage of it, „PopularMechanics.com” 30.10.2015, http://www.popularmechanics.com/ technology/apps/a18018/why-is-siri-a-female-voice/ (dostęp: 9 września 2017).

${ }^{32}$ Dlaczego mój GPS przemawia kobiecym głosem?, ,WP.pl” 14.02.2012, http://kobieta.wp.pl/ dlaczego-moj-gps-przemawia-kobiecym-glosem-5982439402681473a (dostęp: 9 września 2017).

33 W oryginale: „I don't have a gender”.

${ }^{34}$ W oryginale: „Animals and French nouns have genders. I do not”.

35 W oryginale: „In my realm, anyone can be antyhing”.

36 W oryginale: „Hmm, I just don't get this whole gender thing”.

${ }^{37}$ Reklamę można obejrzeć na stronie: https://www.youtube.com/watch?v=1EV7sp8BoWo (dostęp: 9 września 2017). 
Nie jest to strategia charakterystyczna jedynie dla firmy Apple. Podobnie jest w przypadku Amazon Echo, czyli głośnika, który pozwala zdalnie sterować wszystkimi urządzeniami podłączonymi do Internetu — składającymi się na system inteligentnego domu. Jeśli do podstawowego modułu dołączymy specjalnego pilota, Amazon Dash Wand, otrzymamy maszynę, która wykona za nas zakupy. Zamówione produkty dotrą do drzwi naszego mieszkania dzięki kilku prostym komendom wydanym Alexie ${ }^{38}$, czyli posługującej się kobiecym głosem asystentce ${ }^{39}$. W jednym ze spotów promocyjnych mężczyzna (zapewne samotny ojciec) przygotowuje kolację dla siebie i córki ${ }^{40}$. Alexa znów podpowiada szczegóły receptury dania, udziela informacji na temat pogody, planowanych spotkań, opowiada żart, a na koniec dnia odtwarza audiobook, a więc niejako czyta bajkę na dobranoc. Odbiorca reklamy odnosi wrażenie, że robot wchodzi w stereotypową rolę nieobecnej żony/ matki.

Do robotów osobistych ich użytkownicy zwracają się w trybie rozkazującym. W celu przyspieszenia procesu nie stosują form grzecznościowych. Zlecają coś i oczekują natychmiastowej reakcji. Pogłębia to relacje patriarchalne. Z kolei seks-roboty mają być zawsze gotowe na zbliżenie, nie odmawiać i niczego nie oczekiwać. Nawet jeśli wykorzystywanie kobiecego głosu u elektronicznych asystentek miałoby być ,zakorzenione” w ewolucyjnych (,naturalnych”) uwarunkowaniach człowieka czy jego historyczno-cywilizacyjnych „,nawykach”, to nie można zapominać o niebezpieczeństwie przenoszenia sposobu traktowania „kobiet elektronicznych” na kobiety „,realne”/,fizyczne”/,,biologiczne”. Nie chodzi tutaj jedynie o odwzorowanie modelu komunikowania się z Siri bądź Alexą, ale przede wszystkim o pogłębianie stereotypów dotyczących ról i pozycji płci, o podtrzymywanie męskiej hegemonii w świecie, właśnie za pośrednictwem tych maszyn i towarzyszących im przekazów medialnych. Uprzedmiotowione, wyestetyzowane do granic możliwości kobiece ciała w formie humanoidalnych seks-robotów są bardzo jaskrawą ilustracją tego procesu.

Nowe technologie wiązały się z nadziejami emancypacyjnymi, w tym ze zmianami w zakresie postrzegania społeczno-kulturowej roli czy też pozycji kobiet. Spodziewano się, iż wpłyną na względnie trwałe przekształcenia relacji w obszarze stosunków władzy, ekonomii, pracy, a także obyczajowości (między innymi sfery seksualności). Tymczasem, nawet jeśli trudno wyrokować obecnie o tym, czy przyczyniają się one do pogłębienia dotychczas panujących podziałów, to w wypadku asystentek i seks-robotów raczej należy spodziewać się, że przysłużą się one ich podtrzymaniu. Internetowi, komputerom i wielu innym innowacyjnym rozwiąza-

38 Tutaj już bezsprzecznie zostało wykorzystane imię żeńskie.

${ }^{39}$ Komendy głosowe $w$ inteligentnym domu hitem w USA, ,Forbes.pl” 21.03.2016, http://innogy.forbes.pl/inteligentny-dom-amazon-echo-alexa,artykuly,203629,1,1.html (dostęp: 9 września 2017).

${ }^{40}$ Reklamę można obejrzeć na stronie: https://www.youtube.com/watch?v=sulDcHJzcB4 (dostęp: 9 września 2017). 
niom nie można oczywiście odmówić potencjału wolnościowego, rewolucyjnego (co widoczne było choćby w przypadku akcji \#MeToo czy Ogólnopolskiego Strajku Kobiet z 2016 roku), jednak w wypadku maszyn, o których tu mowa, dochodzi do zupełnie odwrotnych procesów. Atrakcyjność androida z osobowością „Frigid Farrah", odmawiającego stosunku seksualnego, bez wątpienia pogłębia relacje podporządkowania funkcjonujące w modelu świata patriarchalnego.

Oczywiście, nie każdy robot jest kobietą. Nie są kobietami chociażby elektroniczni żołnierze, których zadania mają znacznie poważniejszy charakter niż ułatwianie życia czy też zabezpieczenie elementarnych ludzkich „konieczności”. Jednak i owe codzienne potrzeby, gdy chodzi o udział ludzi, nie są aż tak proste do zaspokojenia. Pokazuje to najlepiej przykład Ewy I, czyli ,pierwszego robota kolejkowego" z polskiego serialu komediowego Alternatywy 4, reżyserowanego przez Stanisława Bareję jeszcze w latach osiemdziesiątych.

\section{Is the robot a woman?}

Abstract

The article is devoted to the question of the impact of machines on gender relations. The author points to phenomena that may contribute to maintaining patriarchal patterns of behavior or the deepening of existing stereotypes about the role and position of women and men in contemporary societies. This issue is considered on the example of two types of machines: sex-robots and personal robots, including voice assistants.

Keywords: robot, woman, gender

\section{Bibliografia}

Bakke M., Posthumanizm: człowiek w świecie większym niż ludzki, [w:] Człowiek wobec naturyhumanizm wobec nauk przyrodniczych, red. J. Sokolski, Warszawa 2010.

Brave S., Nass C., Wired for Speech: How Voice Activates and Advances the Human-Computer Relationship, Cambridge 2005.

Cerda C., Robot przyszłości: oszczędzi twój czas, zaopiekuje się domem i jego otoczeniem, rozmowę przeprowadził M. Skubik, „Wyborcza.pl” 9.10.2016, http://wyborcza.pl/1,75400,20811725,robot-przyszlosci-oszczedzi-twoj-czas-zaopiekuje-sie-domem.html.

Chustecki J., Osobiste roboty — wizja przyszłości, „Gazeta.pl” 4.01.2008, http://kobieta.gazeta.pl/ kobieta/1,107880,4809290.html.

Coren Mitchell V., Anyone for robotic rumpy pumpy?, „TheGuardian.com” 30.07.2017, https:// www.theguardian.com/commentisfree/2017/jul/29/anyone-for-robotic-rumpy-pumpy.

Dlaczego mój GPS przemawia kobiecym głosem?, „WP.pl” 14.02.2012, http://kobieta.wp.pl/ dlaczego-moj-gps-przemawia-kobiecym-glosem-5982439402681473a.

Domańska E., Humanistyka nie-antropocentryczna a studia nad rzeczami, „Kultura Współczesna” 2008, nr 3 . 
Dzieliński K., Jia Jia - realistyczny android z Chin, „GeekWeek.pl” 19.04.2016, http://www. geekweek.pl/aktualnosci/26093/jia-jia---realistyczny-android-z-chin.

Friedman M., There's a scientific reason that Siri's voice is female and Siri isn't the first thing to take advantage of it, ,PopularMechanics.com” 30.10.2015, http://www.popularmechanics.com/ technology/apps/a18018/why-is-siri-a-female-voice/.

Grzeszczak A., Stasik P., Robot służący w każdym domu, „Polityka.pl” 13.10.2009, http://www.polityka.pl/tygodnikpolityka/rynek/267464,1, robot-sluzacy-w-kazdym-domu.read.

Hancock E., Robbins S., Sharkey N., Wynsberghe A. van, Our Sexual Future with Robots. A Foundation for Responsible Robotics Consultation Report, The Hague 2017.

Hempel J., Siri and Cortana sound like ladies because of sexism, „Wired.com” 28.10.2015, https:// www.wired.com/2015/10/why-siri-cortana-voice-interfaces-sound-female-sexism/.

Kisiel M., Unia Europejska stworzy prawo dla robotów, „Bankier.pl” 13.01.2017, http://www. bankier.pl/wiadomosc/Unia-Europejska-stworzy-prawo-dla-robotow-7493547.html.

Kleeman J., The race to build the world's first sex robot, „TheGuardian.com” 27.04.2017, https:// www.theguardian.com/technology/2017/apr/27/race-to-build-world-first-sex-robot.

Kleeman J., Silverstone T., Tait M., Rise of the sex robots [wideo], „TheGuardian.com” 27.04.207, https://www.theguardian.com/technology/video/2017/apr/27/rise-of-the-sex-robots-video.

Komendy glosowe $w$ inteligentnym domu hitem $w$ USA, „Forbes.pl” 21.03.2016, http://innogy. forbes.pl/inteligentny-dom-amazon-echo-alexa,artykuly,203629,1,1.html.

Lamża Ł., $W$ dolinie niesamowitości, „TygodnikPowszechny.pl” 21.04.2015, https://www. tygodnikpowszechny.pl/w-dolinie-niesamowitosci-27608.

Maj M., Prawo dla robotów w UE - obowiazkowe „,kill switche” i pojęcie „, osoby elektronicznej”, „Dziennik Internautów” 13.01.2017, http://di.com.pl/prawo-dla-robotow-w-ue-obowiazkowekill-switche-i-pojecie-osoby-elektronicznej-56270.

Michałowska T., Średniowiecze, Warszawa 2002.

Moritz K., Pani robot odpowie na pytania o gdańskim lotnisku, „Trojmiasto.pl” 17.07.2017, https://www.trojmiasto.pl/wiadomosci/Pani-robot-odpowiada-na-pytania-na-gdanskimlotnisku-n114836.html.

Prokop T., Naukowa spekulacja — dlaczego Siri mówi kobiecym głosem?, „WhatNext.pl” 1.11.2015, http://whatnext.pl/dlaczego-siri-mowi-kobiecym-glosem/.

Przegalińska A., Hal śpiewa, Siri milczy, „Dwutygodnik.com” 12, 2011, nr 72, http://www. dwutygodnik.com/artykul/2972-hal-spiewa-siri-milczy.html.

RealDoll, https://secure.realdoll.com/.

Reklama Amazon Echo [wideo], „YouTube.com” 15.09.2016, https://www.youtube.com/ watch? $\mathrm{v}=$ sulDcHJzcB4.

Reklama iPhone 6 [wideo], „YouTube.com” 18.03.2016, https://www.youtube.com/watch?$\mathrm{v}=1 \mathrm{EV} 7 \mathrm{sp} 8 \mathrm{BoWo}$.

Roboty $i$ sztuczna inteligencja: europostowie za odpowiedzialnościa prawna $w$ UE, „rp.pl” 17.02.2017, http://www.rp.pl/Unia-Europejska/302179938-Roboty-i-sztuczna-inteligencjaeuroposlowie-za-odpowiedzialnoscia-prawna-w-UE.html\#ap-1.

Rozwadowska A., Chodzace karty kredytowe. Firma wszczepia pracownikom chipy, „Wyborcza.pl” 5.08.2017, http://wyborcza.pl/7,155287,22175207, chodzace-karty-kredytowe-amerykanskafirma-wszczepia-pracownikom.html.

Sex Bot Company, http://www.sexbots.us/index.html.

Siddique H., Sex robots promise 'revolutionary' service but also risks, says study, „TheGuardian.com” 5.07.2017, https://www.theguardian.com/technology/2017/jul/05/sex-robots-promise-revolutionary-service-but-also-risks-says-study.

Suski M., Głosy w mojej głowie, „Wyborcza.pl” 14.11.2013, http://wyborcza.pl/piatekekstra/1,1291 55,14952022,Glosy_w_mojej_glowie.html. 
TrueCompanion, http://www.truecompanion.com/shop/index.php?p=home.

Używanie funkcji Siri na telefonie iPhone, iPadzie lub iPodzie touch, https://support.apple.com/ pl-pl/HT204389.

Wiseman E., Sex, love and robots: is this the end of intimacy?, „TheGuardian.com” 13.12.2015, https://www.theguardian.com/technology/2015/dec/13/sex-love-and-robots-the-end-ofintimacy.

Prace Kulturoznawcze 21, 2017, nr 3

(C) for this edition by CNS 